\title{
Hacettepe, British Columbia ve Simon Frazer Üniversitelerinde Belge Yönetimi Uygulamalarının Karşılaştırmalı Analizi
}

\author{
Comperative Analysis of the Records Management \\ Practices at Hacettepe, British Columbia and Simon Fraser \\ Universities
}

\section{Özgür KÜLCÜ*}

Öz

Çalışmada Hacettepe Üniversitesi'nde belge yönetimi programlarının geliştirilmesi sürecinde kullanılmak üzere, Kanada ve Türkiye üniversitelerinde belge işlemlerine yönelik uygulamaların karşılaştırılması amaçlanmıştır. Türkiye'de üniversitelerde belge ve arşiv uygulamalarını yönelik idari koşullar, Hacettepe Üniversitesi Beytepe Yerleşkesi örneğinde değerlendirilmiştir. Uluslararası örnek olarak Kanada üniversite sistemi içerisinde yer alan British Columbia ve Simon Fraser Üniversitelerinde belge ve arşiv uygulamalarına ilişkin koşullar, Hacettepe Üniversiesi ile karşılaştırmak üzere incelenmiştir.

Anahtar sözcükler: Belge yönetimi, Arşiv yönetimi, Hacettepe Üniversitesi, British Columbia Üniversitesi, Simon Fraser Üniversitesi

\section{Abstract}

Basic aim of this study is to compare the practices of the records processes in the universities between Canada and Turkey, which may then be used to develop records management programs for Hacettepe University. The administrative condition of the records management

* Yrd.Doç. Dr.;Hacettepe Üniversitesi Edebiyat Fakültesi Bilgi ve Belge Yönetimi Bölümü Beytepe, Ankara (kulcu@hacettepe.edu.tr). 
practices in Turkish universities has been evaluated on the illustrative example of Hacettepe University Beytepe Campus. Furthermore, as an international example, necessary information about records and archival practices has been gathered from the University of British Columbia and Simon Fraser University, in order to prepare a basis for comparison with that of the Hacettepe University.

Keywords: Records management, Archival management, Hacettepe University, University of British Columbia, Simon Fraser University

\section{Giriş}

Kurumlarca üretilen ya da sağlanan belgeler, resmi iletişimi gerçekleştirme işlevlerinin yanı sıra, ilgili oldukları işe yönelik kanıt değeri ve karar verme sürecinde sağladıkları birinci el bilgi ile üretimlerini takip eden belirli bir süre kullanım değeri taşırlar. Bu süreçte belgelerin etkin yönetimi başı başına belge yönetimi disiplininin alanına girmektedir. Kurumlar önceden tanımlanmış bürokratik işleyişleri çerçevesinde belge işlemlerini tanımlamakta ve gerekli çalışmaları yürütmektedirler. Kurumsal belge yönetimi programları, belgelerin üretimden ayıklanmalarına kadar tüm süreçlerde bütünsel yaklaşımları gerektirmektedir. Belge yönetimi programları ile resmi iletişim sürecinin etkinleşmesi, belge düzenleme saklama, erişim ve ayıklama çalışmalarının gereksinimler ve beklentiler çerçevesinde tanımlanması, kurum bütününde uyumlu ve eşgüdümlü uygulamaların gerçekleşmesi amaçlanmaktadır. Belge yönetimi programlarının son aşamasını oluşturan ayıklama işleminin ardında belgeler imha edilmekte ya da kalıcı değerleri olduğuna karar verilirse arşivlere kaldırılmaktadırlar.

Belge yönetimi programlarının uygulama amaçlarını ortaya koyan yukarıdaki unsurlar, ilgili programlar olmadığında ortaya çıkan problemlerin de ana kaynağını oluşturmaktadırlar. Bu çerçevede çalışmada, ülkemizde üniversitelere yönelik belge yönetimi programlarının geliştirilmesi sürecinde kullanılabileceği öngörülen, Kanada ve Türkiye örneklerinden elde edilen veriler karşılaştırılmaktadır.

\section{Terminoloji}

Belge yönetimi kavramı 20. yüzyılın ikinci yarısıyla birlikte, kurumlarda resmi iletişimi gerçekleştirme, iş sürecinin gerektirdiği yasal koşulları 
yerine getirme, yapılanları kayıt altına alma vb. nedenlerle üretilen ya da kullanılan belgelerin; tasarımı ve üretiminden, karar verme sürecinde etkin kullanımına ve buradan arşive kaldırılması ya da imhasına kadar olan süreç kapsamında tanımlanmaya başlanmıştır. Çalışma kapsamında ele alınan kurumsal bilgi kavramı, belge yönetimi programlarının da ana çalışma eksenini oluşturmaktadır. Öte yandan kurumsal bilgi kavramının farklı disiplinlerce ele alınması, çalışma içerisinde kullanılan bazı terimlerin belge yönetimi yaklaşımı çerçevesinde de tanımlanmasını gerekli kılmaktadır. Bu çerçevede belge; kurumsal bir iş sürecinde üretilen ya da kullanılan, geçmişe yönelik uygulamaları ortaya koyan, ilgili çalışmalara kanıt niteliği taşıyan, ortamına bakılmaksızın her türlü dokümanter kaynak olarak tanımlamak mümkündür. Belgeler bağlı oldukları iş sürecini yansıtan, güvenilir ve özgün bilgi içerirler. Bu özellikleri taşıyabilmeleri ve etkin biçimde sürdürebilmeleri için, önceden tanımlanmış, kabul edilmiş formlarda üretilmeleri, eşgüdümlü programlar çerçevesinde ele alınmaları gerekmektedir (Glossary, 1989, s. 16; Penn, Mordel ve Penix, 1994, s. 3). Belge yönetimi olarak tanımlanan bu programlar; "yaşam döngüsü" (life cycle) yaklaşımına dayalı olarak kurumsal boyutta belgelerin üretimi, düzenlenmesi, dağıtımı, alıkonması, ayıklanması ve imhasına yönelik uygulamaları kapsamaktadır (Brumm, 1995; Hare, 1997, s. 3; Penn, Mordel ve Penix, 1994, s. 5; Shiff, 1995, s. 111; Smith, 1997, s. 4). Bu kapsamda belgelerin üretiminin ardında nihai ayıklanmalarına kadar olan süreç, belge saklama planlarında tanımlanmaktadır. Belge saklama planları; seriler düzeyinde kurumsal ve yasal gereklilikler çerçevesinde belgelerin ileriki süreçte geçireceği tüm aşamaları tanımlayan, belge yönetimi programlarının önemli bir unsuru olarak görülmektedir. Belge yönetimi programları ve bu çerçevede uygulanan belge saklama planlarının geliştirilmesi sürecinde yasal ve idari analiz çalışmaları kadar, ulusal ve uluslararası standartlar ve uygulama örneklerinin incelenmesi de gerekli görülmektedir (Montana, 1997, s. 46; Skupsky, 1994, ss. 2-4; Stephens, 1995, s. 75).

Öte yandan ülkemizde belge yönetimi alanında çalışmalar 1990'lı yılların ortalarından itibaren artış göstermiştir. Özdemirci (1996), İçimsoy (1997) ve Kandur (1998) tarafından gerçekleştirilen çalışmalar alanın gelişimine öncülük etmiş, 2000'li yıllarla birlikte ise Çiçek (2000), Külcü (2005) ve Odabaş (2007) belge yönetimini farklı unsurları da 
içine alacak biçimde incelemiştir. Ülkemizde uluslararası belge yönetimi standardı ISO 15489'un farklı açılardan değerlendirildiği çalışmalar (Özdemirci, 2004, ss. 225-246) yanında belge yönetiminde standartlaşma ve uluslararası uygulamaları ele alan çalışmaların da yayımlandığı gözlemlenmiş̧ir (Külcü, 2006, ss. 202-229). Yakın tarihte Türk Standartlar Enstitüsü belge yönetimi konusunda uluslararası standart olan ISO 15489'un Türkçe basımını yayımlamıştır (TS ISO 15489-1, 2007; TS ISO 15489-2, 2007). Ülkemizde gerçekleştirilen bir diğer önemli çalışma, 2005 yılında hazırlanan ve gözden geçirilmiş ikinci baskısı 2006 tarihinde yayımlanan Elektronik Belge Yönetimi Sistem Kriterleri Referans Modeli (EBYSKRM)'dir (Kandur, 2006). Türk Standartları Enstitüsü EBYSKRM'yi 19 Haziran 2007 tarihinde TSE 13298 koduyla standart olarak kabul etmiştir (Türk Standartlar Enstitüsü, 2007).

\section{Araştırma Yöntemi}

Betimleme yönetiminin kullanıldığı araştırmada veriler, literatür incelemesi anket ve görüşme teknikleriyle toplanmıştır. Çalışmanın temel amacı, her iki ülke örneklerinde gerçekleştirilen analizlerden elde edilen verilere dayanarak, Hacettepe Üniversitesi (HÜ) örneğinde Türkiye'de üniversitelerde belge uygulamalarına ilişkin mevcut durumun, sorunların ve bu sorunların çözümüne ilişkin koşulların daha açık olarak tanımlamasına olanak sağlamaktır.

HÜ örneğinde Türkiye'de üniversitelerde belge yönetimi programlarının uygulanmıyor oluşu ciddi bir problem olarak görülmektedir. Bu durum belge işlemlerinin profesyonel kişilerce yürütülememesine, kurumsal iletişim ve eşgüdümü sorunlarına yol açmakta, belgelerin zamanında ayıklanamamakta ve imha edilememekte bu durum belge erişim problemlerinin doğmasını yol açmaktadır. Türkiye'de kamu üniversitelerinde çağdaş ülke örneklerinde olduğu gibi belge yönetimi programlarının uygulanması ve belge saklama planlarının geliştirilmesi sorunların çözümü için gerekli görülmektedir. İlgili programların geliştirilmesine çağdaş ülke örnekleriyle yapılacak karşılaştırmalı çalışmalar katkı sağlayabileceği düşünülmektedir.

Bu çalışmanın verileri yazarın 2005 yılında tamamlanan doktora tezinden elde edilmiştir (Külcü, 2005). HÜ'de gerçekleştirilen anket, HÜ. Beytepe Kampusü'nde belge işlemlerini yürüten ya da bu 
işlemlerde sorumluluğu olan 216 personele gönderilmiş ve sağlanan 186 adedi değerlendirmeye alınmıştır. Bu kapsamda 6 fakülte, 48 bölüm, 5 anabilim dalı, 4 enstitü, 3 yüksek okul, 5 araştırma merkezi ve 17 idari birimde anket uygulanmıştır. Dağıtılan anketin cevaplama oranı \%86,1'dir. Hacettepe Üniversitesi Genel Sekreterliği anketin dağıtımı sorumluluğunu üstlenmiştir.

British Columbia (University of British Columbia-UBC) ve Simon Fraser Üniversitelerinden (Simon Fraser University-SFU) veriler HÜ'de gerçekleştirilen aynı anket formunun Haziran-Ekim 2006 tarihleri arasında uygulanması ile sağlanmıştır. Gerek UBC gerekse SFU'de belge işlemlerinden sorumlu yönetim organı olan belge yönetimi merkezleri anket formalarının dağıtımını üstlenmişlerdir. Bu kapsamda, UBC ve SFU'da merkezi arşiv ve belge yönetimi birimleri ile UBC'ye bağlı Sağlık, Güvenlik ve Çevre Bölümü (Deparment of Health, Safety and Environment), Halkla Iliş̧kiler Bölümü (Department of Public Affairs), Tıbbi Çalışmalar Fakültesi (Faculty of Medical Studies), Antropoloji Müzesi (Museum of Antropology), Üniversite Güvenlik Birimi (Unit of University Security) ve UBC Rektörlük Makamında (University Chancellor of UBC) inceleme ve anket çalışmaları yürütülmüştür. UBC ve SFU'da dağıtılan toplam 76 anket formundan geri dönen 48'i değerlendirmeye alınmıştır. Kanada örneklerinde ankete yanıt verme oranı \%63,15'dir.

HÜ ile UBC ve SFU'de belge işlemlerine dönük idari sistemi ayıran temel fark, UBC ve SFU'da belge ve arşiv yönetimi uygulamalarına dönük merkezi bir birimin olması, ancak aynı örgütlen-menin HÜ'de bulunmamasıdır. Bundan ötürü UBC ve SFU kurumsal belge yönetimi uygulamalarına dönük bilgiler, merkezi birimlerden sağlanabilirken HÜ'de farklı uygulamalara ilişkin bilgilerin sağlanabilmesi için daha kapsamlı analizlerin yapılması gerekmiştir. Anket çalışmalarının analizi için "en yaygın kullanılan teknik olan tanımlayıcı istatistik" tekniğinden yararlanılmıştır (Baş, 2001, s. 128). Anket çalışmalarında kullanılan tanımlayıcı istatistikler; toplamları (sayı ya da frekanslar), oranları (yüzdeler), ortalamaları (aritmetik ortalama mod medyan) ve değişken ölçülerini (değişim aralığı standart sapma) içermektedir. 
Bulguların değerlendirilmesinde, SPSS (Statistical Package for Social Sciences) kullanılmıştır. İlgili programa sayısallaştırılarak girilen verilerin frekans değerleri, çapraz tabloları ile gruplar arasındaki doğrusal ya da ters ilişkiler saptanmıştır. Grupların kendi içerisinde ve gruplar arasında verilen yanıtları daha sağlıklı biçimde karşılaştırabilmek için grupların verdikleri yanıtların toplanması ve elde edilen sonucun toplam birim sayısına bölünmesiyle elde edilen (Baş, 2001, s.142) aritmetik ortalama değerleri $(\bar{X})$ hesaplanarak ilgili tablolara yansıtılmıştır.

Aritmetik ortalama değeri, toplam beş değişken olarak hazırlanan ankette, her değişkene verilen yanıtlar, grupların kendi içerisinde ve gruplar arasında karşılaştııımiştir. Anket bulguları değerlendirilirken, tablolar içinde yer alan aritmetik ortalama değerleri, en düşük değer olan bir ile en yüksek değer olan beş temel alınarak hesaplanmıştır.

Olumlu Yaklaşım Olumsuz Yaklaşım

$\begin{array}{llll}\text { 1. Sırada/ Hiç (f1) } & 5 & 1 \\ \text { 2. Sırada/ Az (f2) } & 4 & 2 \\ \text { 3. Sırada/ Orta (f3) } & 3 & 3 \\ \text { 4. Sırada/ Çok (f4) } & 2 & 4 \\ \text { 5. Sırada/ Tam (f5) } & 1 & 5\end{array}$

Bu veriler doğrultusunda aritmetik ortalama değerleri,

$=(f 1+f 2+f 3+f 4+f 5) \quad / \quad 5$ formülünden çıkan sonuçlar doğrultusunda hesaplanarak ilgili tablolara yansıtılmıştır.

Aritmetik ortalama değerinin hesaplanmasında, grupların verdikleri yanıtlarda tutarsızlık olması, değerlerin sapmasına yol açabilmektedir. Aritmetik ortalama değerinden sapmaların ortaya konulabilmesi için ilgili tablolara ilişkin standart sapma değerlerinin de saptanması gerekli görülmektedir (Baş, 2001, ss. 127-131).

$$
\mathrm{s}=\sum(\mathrm{x} \text {-xort)2 / (n-1) }
$$

Yukarıdaki formülden elde edilen standart sapma değerleri, ilgili konuda uzman kişilerle koordineli biçimde hesaplanmıştır. Yapılan 
çalışmalar doğrultusunda, 0,750'den küçük standart sapma değerleri; deneklerin yanıtlarının belirli bir noktada yoğunlaştığı ve yanıtlar arasında hiçbir sapma olmadığını, 1,000'dan küçük olan değerler, yanıtların belirli sonuçlar üzerinde yoğunlaştığını ve sapma olmadığını, 1,250 'den büyük değerler, deneklerce verilen yanıtların dağınık ve ama kabul edilebilir düzeyde olduğunu, 1,500'ün üzerindeki değerler ise deneklerce verilen yanıt sayısının ya çok küçük bir küme oluşturduğunu ya da birbirlerinden oldukça faklı değişkenler üzerinde dağınık olarak sıralandığını ve sapma olduğunu ortaya koymaktadır.

Her iki ülkede aynı içerikte uygulanan anket sorularında birden fazla seçenek işaretlenmesinin beklendiği (ilgili anket formlarında açıklayıcı bilgilerin verildiği) kimi sorularda, Kanada örneklerinin tek şık üzerinde yoğunlaştığı görülmüştür. Bu çerçevede Türkiye örneğinde uygulanan anket formları analiz edilirken ilgili yanıtlar \%100'e çevirilerek hesaplanmıştır.

\section{HÜ, UBC ve SFU'ya İlişkin Genel Bilgiler}

Tablo 1'de çalışma kapsamında değerlendirilen Hacettepe, British Columbia ve Simon Fraser üniversitelerine ilişkin genel içerikli bilgiler yer almaktadır.

Tablo 1. HÜ, UBC ve SFU'ya İlişkin Genel Bilgiler

\begin{tabular}{rrrr}
\hline & HÜ & UBC & SFU \\
\hline Kuruluş & 1967 & 1908 & 1965 \\
\hline Sıralama & 409. & 37. & 339. \\
\hline Öğr.Say. & 30.000 & 45.000 & 25.000 \\
\hline Bütçe (\$) & 235.059 .000 & 1.254 .946 .000 & 479.000 .000 \\
\hline
\end{tabular}

(Hacettepe, 2006;Simon Fraser, 2006;Toope, 2006)

HÜ ve SFU'nin yakın tarihlerde kurulduğu, UBC'nin ise yüzyılın ilk çeyreğinde eğitim-öğretim faaliyetlerine başladığı görülmektedir. Üç

"Çin'in Şanghay Jiao Üniversitesi tarafından yapılan, "Dünyanın En iyi 500 Üniversitesi 2005" listesine göre dünya sıralamasından alınmıştır: Top 500 World Univesities. 10.12.2006 tarihinde http://ed.sjtu.edu.cn/rank/2006/ARWU2006TOP500list.htm adresinden erişildi. 2006 senesininde listeye Türkiye'den hiç bir üniversite girememiştir. 2007 senesinde ise İstanbul Üniversitesi 472. sırada girmiştir. 
üniversitenin de öğrenci sayıları 25-45 bin civarında iken, 2005 bütçe gerçekleşmelerine göre UBC'nin yıllık bütçesi diğer iki üniversite toplamının iki katına yakındır. 2006 yılında yayımlanan Şangay Jiao Üniversitesinde gerçekleştirilen ve üç üniversitenin de yer aldığı dünya üniversiteleri sıralamasında UBC 37. sırayı alırken SFU 339. ve HÜ 409. sırada yer bulabilmişlerdir.

\section{UBC/SFU ve HÜ'de Personelin Mesleki Eğitimi}

Kanada ve Türkiye örneklerinde belge işlemlerini yürüten personelin, mesleki eğitim alt yapısına ilişkin veriler Tablo 2'de yer almaktadır.

Tablo 2. UBC/SFU ve HÜ'de Personelin Belge İşlemlerine Dönük Eğitimi

\begin{tabular}{lcc}
\hline & UBC/SFU & HÜ \\
\hline $\begin{array}{l}\text { Bilgi ve Belge Yönetimi Alanında Bir Okuldan } \\
\text { Mezun }\end{array}$ & 37,5 & 5,1 \\
\hline $\begin{array}{l}\text { Alanda Formasyonu Ama Hizmet İçi Eğitim } \\
\text { Kurs vb. Katılmış }\end{array}$ & 37,5 & 10,2 \\
\hline $\begin{array}{l}\text { Alanla İlgili Herhangi Bir Eğitim Çalışmasına } \\
\text { Katılmamış, Kendi Deneyimleri İle Işlemleri } \\
\text { Yürütüyor }\end{array}$ & 25,0 & 84,7 \\
\hline \multicolumn{1}{c}{ Toplam } & 100,0 & 100,00 \\
\hline
\end{tabular}

Yukarıdaki veriler doğrultusunda, UBC/SFU ve HÜ'de belge işlemlerini yürüten personelin mesleki eğitim altyapısının birbirinden oldukça farklı olduğunu söylemek mümkündür. Türkiye örneğinde belge işlemlerini yürüten ya da bu işlemlerden sorumlu personelin ancak $\% 5,1 \mathrm{i} i$ ilgili alandan mezun olduğunu dile getirirken, bu oran Kanada örneklerinde \%37,5'e çıkmaktadır. Türkiye örneğinde personelin önemli bir bölümünün yürüttüğü belge işlemlerini kendi deneyimlerine dayanarak geliştirdiğini dile getirmesi $(\% 84,7)$, ilgili alanda eğitim gereksiniminin bir parçası olarak değerlendirilmelidir. Bu durum kurumlarda uyumlu ve eşgüdümlü çalışmaların yürütül-mesini olumsuz yönde etkileyebileceği gibi, kurumsal uygulamaların sistem yaklaşımının dışında kişilere bağımlı kalmasına neden olabilecek, uygulamalarda süreğenliğin sağlanmasında ciddi aksaklıklara yol açabilecektir. 


\section{UBC/SFU ve HÜ'de Kullanılan Belge Türleri}

Kanada ve Türkiye'de belge işlemlerinde kullanılan belge türlerine yönelik Tablo 3'de yer alan veriler, belge işlemlerinde yazışmalar, raporlar ve formların her iki ülke içerisinde de yaygın olarak kullanıldığını göstermektedir. Betimsel istatistiklere göre her iki ülkedeki belge türleri arasında ağılık; yazışmalar, formlar ve raporlarda yoğunlaşmaktadır. Öte yandan Kanada örneklerinde elektronik ortamda iletişimi sağlamakta e-postadan yaygın olarak yararlanılmaktadır. Bu durum, UBC ve SFU'de rutin yazışmaların eposta aracılığıyla iletimini, dolayısıyla Türkiye örneğinde yazışmalarda görülen yoğunluğun Kanada örneklerinde yaşanmaması sonucunu doğurmaktadır. Yine Kanada örneklerinde belge yönetimi programlarının uygulanıyor oluşundan ötürü, saklama planları ve buna bağlı olarak oluşturulan veri tabanı raporlarının belge türleri içerisinde yer aldığı görülmektedir.

Tablo 3. UBCSFU ve HÜ'de Belge İşlemlerinde Kullanılan Belge Türleri

\begin{tabular}{lcc}
\hline & UBC/SFU & HÜ \\
\hline Yazışmalar & 25,0 & 46,5 \\
\hline Talimatlar & 8,3 & 13,3 \\
\hline Raporlar & 27,1 & 20,1 \\
\hline Formlar & 12,5 & 20.1 \\
\hline E-Posta & 16,7 & - \\
\hline Diğerleri (Saklama planları,Veri tabanları) & 6,3 & - \\
\hline Veritabanı Raporları ( Database reports) & 4,1 & - \\
\hline
\end{tabular}

\section{UBC ve SFU'de Belgelerin Üretildiği Ortamlar}

Belgelerin üretildiği ortamlara ilişkin veriler, sadece Kanada'daki uygulamalara aittir. Türkiye üniversitelerine örnek olarak alınan HÜ'nde, elektronik ortamda üretilen ya da kullanılan belgeler (burada resmi işlemlerde geçerliliği olan, genellikle elektronik imza sertifikasına sahip belgeler kastedilmektedir) var olan belge sistemi içerisinde yer almadığı için, Tablo 4'deki istatistikler Kanada örneklerindeki uygulamaları yansıtmaktadır. 
Tablo 4. UBC ve SFU'de Belgelerin Üretildiği Ortamla \%

\begin{tabular}{lc}
\hline Kağıt (Paper) & 39,4 \\
\hline Elektronik (Electronic) & 46,4 \\
\hline Kartografik (Cartographic) & 7,1 \\
\hline Mikrofilm (Microfilm) & 7,1 \\
\hline
\end{tabular}

Kanada'da incelemelerin yürütüldüğü UBC ve SFU içerisinde elektronik belgeler yaklaşık olarak üretilen toplam belgelerin yarısı kadardır. Kurumsal işlemlerde elektronik belgelerin kullanımının 10-15 yıllık mazisi olmasına karşın, Kanada örneklerinde üretilen belge-lerin yarısına yakınına ulaşması, belge ortamlarında kısa sayılabi-lecek sürede gerçekleşen değişimin boyutunu ortaya koymaktadır. Öte yandan 2004 yılında yürürlüğe giren "Elektronik İmza Kanunu” ile Türk Hukuk Sistemi içerisinde elektronik belgelerin kanıt niteliği-nin kabul edilmesine ve elektronik imza servis sağlayıcılarının varlı-ğına karşın, Türkiye'de kamu ve özel sektör içerisinde elektronik belgelerin kullanımı henüz yaygınlık kazanamamıştır.

\section{Üretilen Belgelere Erişim Yöntemi}

Her iki ülkede inceleme yapılan üniversitelerin idari sistemleri içerisinde, belge erişimine dönük uygulanan yöntemlere ilişkin veriler Tablo 5'de yer almaktadır. Bu veriler doğrultusunda, her iki ülkede inceleme yapılan alanlarda, geçmişte üretilen belgelere erişim için, öncelikle güncel dosyalardan yararlanıldığını söylemek mümkündür (UBC/SFU \%62,5; HÜ \%36,7). UBC/SFU'de geçmişte üretilen belgelere erişim için ikinci sırada Web sayfasından yararlanıldığı dile getirilirken $(\% 37,5)$, HÜ'de birim arşivlerinden yararlanmanın ikinci sırada yer aldığı görülmektedir $(\% 30,5)$.

Tablo 5. Kurumca Üretilen Belgelere Erişim Yönetimi

\begin{tabular}{lcc}
\hline & UBC/SFU & HÜ \\
\hline Güncel dosyalardan & 62,5 & 36,7 \\
\hline Birim arşivlerinden & 25 & 30,5 \\
\hline Diğer birim arşivlerinden & 12 & 19,4 \\
\hline Web sayfasından & 37,5 & 13,4 \\
\hline
\end{tabular}




\section{Belgelere Erişime Yönelik Kullanılan Erişim Araçları (Finding Aids)}

Her iki ülkede inceleme yapılan alanlarda, belgelere erişimde hangi erişim araçları (finding aids)'nın kullanıldığına yönelik verilerin analizi sonucu Tablo 6'da ortaya konulmuştur.

Tablo 6. Belgelere Erişime Yönelik Kullanılan Erişim Araçları ${ }^{*}$

\begin{tabular}{lcc}
\hline & UBC/SFU & HÜ \\
\hline Envanterler, kataloglar, indeksler & 44,4 & 77,4 \\
\hline $\begin{array}{l}\text { Doğrudan belgelerin yer aldığı dosyaların } \\
\text { taranması }\end{array}$ & 12,6 & 67,7 \\
\hline Geliştirilmiş otorite dosyalar yardımıyla & 70 & 47,3 \\
\hline Elektronik katalog, indeks ya da listelerden & 60,2 & 19,9 \\
\hline
\end{tabular}

Belgelere erişimde, HÜ'de yaygın olarak envanterler (burada kastedilen gelen ve giden evrak defterleri), kataloglar ve indeksler kullanılırken $(\% 77,4)$, UBC ve SFU'de özel olarak geliştirilmiş otorite dosyalardan (knowledge of the files) yaygın olarak yararlanılmaktadır (\%70). Doğrudan belgelerin yer aldığı dosyaların taranması ile belgelere erişim, Kanada'da \%12,6'da kalırken, bu oran HÜ'de \%67,7'ye çıkmaktadır. Yine UBC ve SFU'de belge erişimde elektronik ortamda yararlanma oranı \%60,2 gibi yüksek bir düzeydedir. Bu oran HÜ'de \%19,9'da kalmaktadır.

\section{Belgelerin Güncel Dosyalarda Saklama Süreleri}

Her iki ülke örneklerinde güncel dosyalarda belgelerin saklama sürelerine ilişkin verilerin yer aldığı Tablo 7 çerçevesinde, UBC ve SFU'de güncel dosyalarda belgelerin 5 (\%25) ile 7 yıl $(\% 37,5)$ kalma olasılığının \%50'den fazla olduğunu söylemek mümkündür. Öte yandan HÜ'de deneklerin yarıdan fazlası (\%54) güncel dosyalarda ayıklama çalışmasının yapılmadığını belirtmişlerdir. Bu durum HÜ'deki deneklerin yarıdan fazlasının belge saklama planlarına sahip olmadığını göstermektedir. Öte yandan UBC ve SFU'de belgelerin güncel dosyalarda sürekli alıkonulduğunu belirtenlerin oranının \%6,3 çıkması dikkat çekicidir. HÜ'de deneklerin \%25’i belgelerin güncel dosyalarda 5 yıl, \%13,7'si ise 10 yıl alıkonulduğunu ifade etmiştir. UBC

*Yukarıdaki tabloda denekler birden çok seçenek işaretlediklerinden oranlar \%100'ün üzerinde çıkmaktadır. 
ve SFU'de saklama süresinin belge türüne göre değiştiğini belirten $\% 18,8^{\prime}$ lik kesim, bu oranda ayrıntılı saklama uygulamalarının gerçekleştiğini de ortaya koymaktadır.

Tablo 7. Güncel Dosyalarda Belge Saklama Süreleri

\begin{tabular}{lcc}
\hline & UBC/SFU & HÜ \\
\hline 1 YII & 7,2 & 0,7 \\
2 YII & 6,3 & 1,4 \\
5 YII & 25,0 & 24,7 \\
7 YII & 37,4 & - \\
10 YII & - & 13,7 \\
20 YII & - & 2,3 \\
Belge türüne göre değişken & 17,8 & 2,4 \\
Sürekli olarak & 6,3 & 54,8 \\
\hline
\end{tabular}

\section{Kurumlarda Belge Saklama ve Ayıklama Yöntemleri}

Araştırmaların yürütüldüğü kurumlarda yarı güncel ya da güncelliğini kaybetmiş belgelerin saklama ve ayıklama yöntem-lerine ilişkin veriler Tablo 8'de yer almaktadır.

HÜ'de deneklerin güncelliğini kaybetmiş belgelere yönelik yaygın uygulaması, belgeleri herhangi bir ayıklama çalışmasına tabi tutmadan toplu olarak arşive kaldırılması şeklindedir. Öte yandan UBC ve SFU'de uygulamaların \%50'sini, belgelerin seriler düzeyinde saklama planlarında tanımlandığı gibi ayıklanması oluşturmaktadır. Bu farklılığın en önemli nedeni, HÜ'de belge saklama planlarının, dolayısıyla saklama şemalarının geliştirilmemiş olmasıdır. Öte yandan HÜ'de, belgeleri kendi belirledikleri düzen içerisinde önceliklerine göre ayırıp ayıklama işlemini bu şekilde gerçekleş-tirenlerin oranı \%36,8'dir. UBC ve SFU'de belgelerin ayıklama yapmadan toplu olarak imha ettiğini belirten \%25'lik kesim, ilgili alanda ciddi bir soruna işaret etmektedir. Bu seçeneğin HÜ'de işaretlene oranının \%4,5'de kalması olumlu değerlendirilmektedir. 
Tablo 8. Kurumlarda Belge Saklama ve Ayıklama Yöntemleri

\begin{tabular}{lcc}
\hline & UBC/SFU & HÜ \\
\hline $\begin{array}{l}\text { Değerlendirme yapılmadan toplu olarak } \\
\text { ayıklanıyor }\end{array}$ & 25,0 & 4,5 \\
\hline $\begin{array}{l}\text { Belgeler önceliğine göre ayrılıp sınıllandırılarak } \\
\text { ayıklama yapılıor }\end{array}$ & 8,3 & 36,8 \\
\hline Doğrudan üniversite arşivine gönderiliyor & 16,7 & 4,5 \\
\hline $\begin{array}{l}\text { Seriler düzeyinde saklama planlarında } \\
\text { tanımlandığı gibi ayıklanıyor }\end{array}$ & 50,0 & -- \\
\hline $\begin{array}{l}\text { Güncelliğini kaybetmiş belgeler kalıcı depolara } \\
\text { herhangi bir ayıklama yapılmadan gönderiliyor. }\end{array}$ & - & 54,2 \\
\hline
\end{tabular}

\section{Arşive Kaldırılan Belgelerin Saklama Süreleri}

Her iki ülkede inceleme yapılan üniversitelerde, güncelliğini kaybetmiş ancak kullanım değerlerinden ötürü çalışma ortamlarından kalıcı depolara kaldırımış belgelerin, arşivlerde saklama sürelerine ilişkin veriler Tablo 9'da yer almaktadır.

Güncelliğini kaybeden belgelerin arşivlerde saklama sürelerine ilişkin Tablo 9'da yer alan veriler, her iki ülke arasındaki uygulama farklılıklarını ortaya koyması bakımından önemli görülmektedir. HÜ'de belge saklama planlarının uygulanmıyor oluşu, belge işlemlerinde uzmanlaşmış personel eksikliği vb. sorunlardan ötürü, güncel ortamlardan ayıklanamayan belgeler, daha sonra arşivlerde ayıklanmaya çalışılmaktadır. HÜ'de $\% 70$ gibi yüksek oranda arşivlerde 5 yılın ardından belgelerin imha edildiğinin dile getirmesi bu yargıyı desteklemektedir. Oysa UBC ve SFU'de deneklerin yarısı arşivlerde imha çalışmasının yapılmadığını belirtmişlerdir. Bu durum belge imha çalışmalarının önemli bir bölümünün belgeler arşive gelmeden güncel depolarda gerçekleştirilmesinden kaynaklan-maktadır. Böylece arşiv çalışmalarında rahatlama sağlandığı gibi, güncel ortamlarda gereksiz belgelerin yarattığı yer ve depolama sorunu ile erişim problemleri de azaltılabilmektedir. HÜ'de belge yönetimi programları ve belge saklama planlarının uygulanmıyor oluşunun, bu sonucun ortaya çıkışında önemli bir neden olduğu düşünülmektedir. 
Tablo 9. Arşive Kaldırılan Belgelerin Saklama Süreleri

\begin{tabular}{lcc}
\hline & UBC/SFU & HÜ \\
\hline Arşivde 1 yılın ardından gereksiz belgeler imha ediliyor & 12,5 & 15,5 \\
\hline 5 yılın ardından gereksiz belgeler imha ediliyor & -- & 70,1 \\
\hline 10 ylın ardından gereksiz belgeler imha ediliyor & 12,5 & 5,2 \\
15 ylın ardından gereksiz belgeler imha ediliyor & 12,5 & 6,7 \\
\hline 20 yilın ardından gereksiz belgeler imha ediliyor & -- & 2,5 \\
\hline İmha belge saklama şemaları çerçevesinde yapılıyor & 12,5 & -- \\
\hline Arşivde ayıklama yapılmıyor & 50 & -- \\
\hline
\end{tabular}

\section{Belge İşlemlerine Yönelik Harcanan Süre}

UBC, SFU ve HÜ'de belge işlemlerini yürüten ya da bu işlemlerden sorumlu personelin belge işlemlerine yönelik harcadığı süreye ilişkin bilgiler Tablo 10'dan izlenebilmektedir.

Her iki ülke örneklerinde belge işlemlerini yürüten personelin, bir iş günü içerisinde belge işlemlerine yönelik olarak ortalama harcadığı süre 2 ile 5 saat arasında değişmektedir. UBC SFU'de belge işlemlerine yönelik bir iş günü içerisinde 5 saatten fazla zaman ayıran personel ilk sırada iken HÜ'de 2-4 saat arasının işaretlenme oranı ilk sıradadır. Diğer değişkenlere yanıtlar karşılaştırmaya gerek duyulmayacak yakınlıkta gerçekleşmiştir.

Tablo 10. Belge İşlemlerine Yönelik Harcanan Süre

\begin{tabular}{lcc}
\hline & UBC/SFU & HÜ \\
\hline 5 saatten çok & 37,5 & 16,4 \\
\hline 2-4 saat arası & 12,5 & 37,2 \\
\hline 1 saatten az & 25,0 & 26,1 \\
\hline 30 dakikadan az & 25,0 & 20,3 \\
\hline
\end{tabular}

\section{UBC, SFU ve HÜ'de Belge İşlemlerine Yönelik İdari Koşulların Karşılaştırılması}

Bu bölümde yer alan değişkenler, her iki ülke örneklerinde belge işlemlerine yönelik idari koşuları değerlendirmeye yönelik olarak hazırlanmıştır. Her iki ülke örneklerinde Likert ölçeklemesi çerçevesinde 5 değişken üzerinden hazırlanan anket formları 
değerlendirilirken, aritmetik ortalama değerleri temel alınmıştır. Aritmetik ortalama değerlerinde "bir"e yaklaşan veriler olumsuz yargıyı "beş"e yaklaşan veriler de olumlu yargıyı desteklemektedir.

Tablo 11. UBC/SFU ve HÜ'de Belge İşlemlerine Yönelik İdari Koşulların Karşıllaştırması

\begin{tabular}{ccccccc}
\hline & A & B & C & D & E & F \\
\hline $\begin{array}{l}\text { UBC/SFU } \\
\bar{X} *\end{array}$ & 2,75 & 2,33 & 2,83 & 3,33 & 3,25 & 3,70 \\
\hline $\mathbf{s}$ &, 753 &, 778 & 1,02 &, 887 &, 753 &, 483 \\
\hline $\mathbf{H U ̈}$ & 2,79 & 2,85 & 2,75 & 2,75 & 2,47 & - \\
$\bar{X}$ &, 915 &, 966 &, 964 & 1,01 & 1,09 & - \\
\hline $\mathbf{s}$ & &
\end{tabular}

*Aritmetik ortalama değerleri aşağıdaki değişkenler üzerinden hesaplanmıştır:

1-Kesinlikle Katımıyorum 2.Katılmıyorum 3.Karasızım 4. Katılıyorum 5. Kesinlikle Katılıyorum

Kurumda idari sistem herhangi bir problem olmaksızın işlemektedir yargısı

Tablo 11'de yer alan veriler doğrultusunda, her iki ülke örneklerinde üniversitelerin idari yapısına ilişkin sorunların yoğunluğunun yakın düzeylerde olduğunu söylemek mümkündür. İdari sistemin sorunsuz biçimde işlediğine ilişkin yargıya yanıtlarların aritmetik ortalamaları, kararsız seçeneğinden ( $\bar{X}$ 3,0000) daha düşük düzeyde, katılmıyorum seçeneğine $(\bar{X} 2,0000)$ yakın oranlarda gerçekleşmiştir. Bu sonuç her iki ülke için de benzer düzeylerdedir (UBC ve SFU : $\bar{X} 2,7500$; HÜ: $\bar{X}$ 2,7977).

A- Kurumda yöneticiler ve çalışanlar arasında herhangi bir iletişim ve eşgüdüm problemi yoktur yargısı

Belge işlemlerini yürüten personel ile ilgili çalışmalardan sorumlu personel arasında iletişim ve eşgüdüm problemlerinin, UBC ve SFU'de HÜ'de daha yoğun yaşandığı görülmektedir. UBC ve SFU'de aritmetik ortama değerinin daha düşük çıkması (UBC ve SFU : $\bar{X}$ 2,3333; HÜ: $\bar{X} 2,8580$ ) bu yargıуı desteklemektedir. 
B- Çalışanlar arasında herhangi bir iletişim ve eşgüdüm problemi yoktur yargısı

Çalışanların kendi aralarında iletişim ve eşgüdüm sorunu konusunda, her iki ülke örneklerinde birbirlerine yakın oranlar söz konusu olmakla birlikte, HÜ'de, UBS ve SFU'negöre bir miktar daha yoğun sorunlar yaşandığı görülmektedir (UBC ve SFU : $\bar{X}$ 2,8333; HÜ: $\bar{X}$ 2,7584).

C- Kurum içerisinde idari koşullar ve yasal düzenlemeler, yürütülen çalışmaların gerektiği ve istenildiği biçimde gerçekleşmesine olanak sağlamaktadır yargısı

HÜ'de katılımcılar, belge işlemlerine yönelik idari ve yasal düzenlemelerin, ilgili çalışmaların istenildiği gibi ve beklentilere uygun olarak gerçekleştirilmesinde yetersiz olduğunu, Kanada örneklerine göre çok daha güçlü biçimde dile getirmektedirler (UBC ve SFU : $\bar{X}$ 3,3333; HÜ: $\bar{X}$ 2,75863).

D- Belgelere yönelik mevcut koşullar, resmi iletişimi sağlamada, yasal gereklilikleri yerine getirmede ve yönetsel kararların zamanında ve doğru olarak alınmasında yetersizdir yargısı.

HÜ'de katılımcılar, üniversite sistemi içerisinde belge işlemlerine yönelik uygulamaların, daha sorunlu olduğunu ve var olan sistemin etkin olmadığını daha yüksek bir oranda dile getirmektedirler (UBC ve SFU : $\bar{X}$ 2,4757; HÜ: $\bar{X}$ 3,250).

E- Hacettepe Üniversitesi ile ilgili üniversiteler arasında gerçekleştirilen çalışmanın, Türkiye'de üniversitelere yönelik belge yönetimi programlarının geliştirilmesine olumlu katkı sağlayacağı yargısı.

Bu kapsamda son soru UBC ve SFU'da belge işlemlerini yürüten personele, gerçekleştirilen incelemelerin HÜ'de ve genel olarak Türkiye'de üniversitelere yönelik belge yönetimi programlarının geliştirilmesine katkısı olup olmayacağına yönelik sorulmuştur. Yanıtlar böyle bir çalışmanın olumlu katkı yapacağına güçlü bir desteğin olduğunu göstermektedir (UBC ve SFU : $\bar{X} 3,700$ ). 


\section{İdari Koşullar ve Belge İşlemlerine Yönelik Yaşanan Sorunların Kaynağı}

Bu bölümde her iki ülkedeki katılımcılara, kendi kurumları içerisinde yönetim sistemi, iletişim kanalları, resmi iletişim ve belge işlemlerine yönelik sorunların var olup olmadığı sorulmuş, yanıtların aritmetik ortalamaları ve yüzdeleri alınarak karşılaştırılmıştır. Çoktan seçmeli ve öncelik sırasına göre yanıtlanan bu bölümde, elde edilen yanıtlarda aritmetik ortalama değerlerinin düşük çıkması, ilgili değişkenin sorunlar arasındaki önceliğini göstermektedir.

Tablo 12. İdari Koşullar ve Belge İşlemlerine Yönelik Yaşanan Sorunların Kaynağı

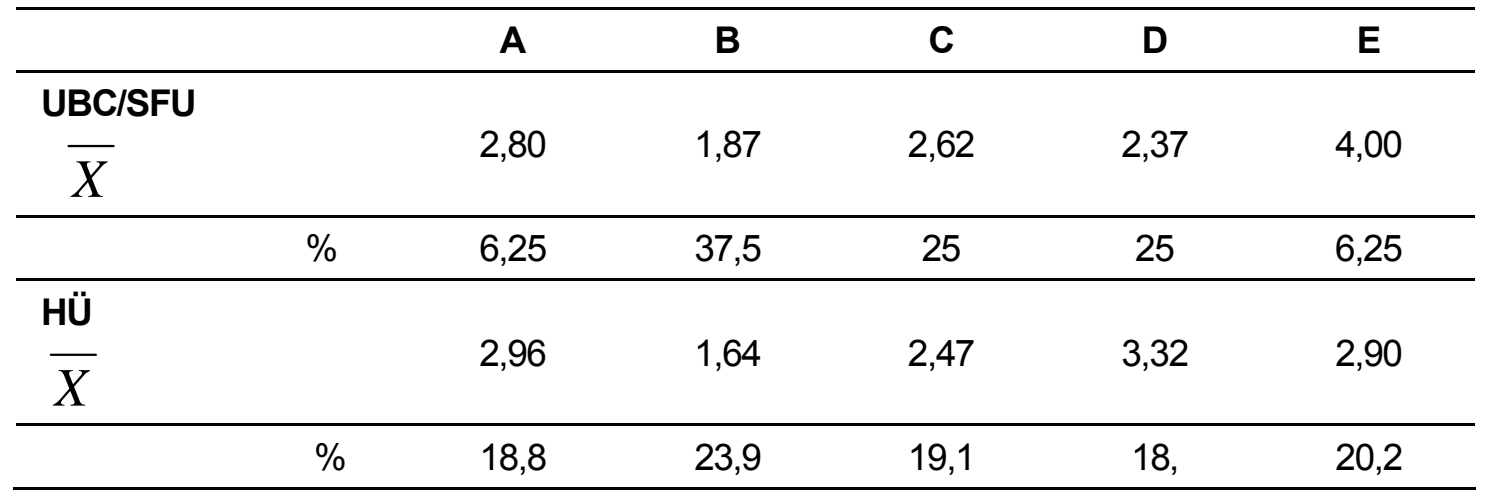

\section{A- Yöneticilerin ilgisizliği}

Yapılan analizler, her iki ülke içerisinde idari koşullar ve belge işlemlerine yönelik sorunlar arasında "yöneticilerin ilgisizliği"nin, çok yoğun olmamakla birlikte yaşandığını göstermektedir (UBC ve SFU : $\bar{X}$ 2,800; HÜ: $\bar{X}$ 2906). Her iki ülke örneklerinde elde edilen veriler, güçlü olmamakla birlikte bu yargıyı desteklemektedir. Öte yandan seçeneğin işaretlenme yüzdesi, HÜ'de \%18,8 iken,UBC ve SFU'de $\% 6,25$ 'de kalmaktadır. Bu durum HÜ'deki deneklerin yöneticilerin ilgisizliğine yönelik daha yaygın sorunlarla karşılaştıklarını göstermektedir.

\section{B- Etkin olmayan bürokrasi ve iletişim kanallarının yavaşlığı}

Deneklerce, her iki ülkede üniversite idari sistemleri içerisinde yaşanan sorunların en önemli kaynaklarından birisi olarak, etkin olmayan bürokratik yapı ve iletişim kanallarının yavaşlı̆̆ı gösterilmektedir. Seçeneğin aritmetik ortalama değerlerinin her iki ülke içerisinde de 
küçük çıkması ve işaretlenme oranının yüksekliği (UBC ve SFU : $\bar{X}$ 1,8750-\%37,5; HÜ: $\bar{X}$ 1,6434-\%23,9) bu yargıyı desteklemektedir.

\section{C- Resmi iletişimi sağlayan belgelere yönelik etkin bir sistemin olmayışı}

Yoğunlukla resmi iletişimi gerçekleştirmek üzere üretilen ya da kullanılan belgelere yönelik etkin bir sistemin olmayışı, idari sorunlar arasında HÜ'de 2. UBC ve SFU'de 3. sırada gösterilmiştir. HÜ'de ilgili soruyu çoktan seçmeli olarak birden fazla seçenek işaretleyen deneklerin \%19,1'i ilgili konuda sorun yaşadığını dile getirirken, ilgili seçeneğin işaretlenme oranı UBC ve SFU'de \%25'e çıkmıştır (UBC ve SFU : $\bar{X}$ 2,6250-\%25; HÜ: $\bar{X}$ 2,4757-\%19,1

\section{D- Gerekli belgelere zamanında erişimin sağlanamaması}

UBC ve SFU'de idari sistem içerisinde gerekli belgelere zamanında erişim probleminin, HÜ'ne göre daha yoğun yaşandığı görülmektedir. İlgili seçeneğin UBC ve SFU'de işaretlenme oranı \%25 civarında iken, bu oran HÜ'de \%18'dir. HÜ'de aritmetik ortalama değerinin yüksek çıkması sorunun önceliğini arka sıralara itmektedir. (HÜ: $\bar{X} 3,3265$ ). Erişim problemi diğer seçenekler arasında UBC ve SFU'de ikinci sırada önemli gösterilmiştir (UBC ve SFU : $\bar{X}$ 2,3750).

\section{E- Çalışanların tutum ve davranışlarından kaynaklanan problemler}

İdari koşullar ve belge işlemlerine yönelik yaşanan sorunların kaynakları arasında çalışanların tutum ve davranışları, UBC ve SFU'de diğerleri arasında son sırada önemli gösterilirken (UBC ve SFU : $\bar{X}$ 4,0000), HÜ'de 3. sırada önemli gösterilmiştir (HÜ: $\bar{X} 2,9000$ ). Öte yandan ilgili seçeneğin işaretlenme yüzdesi HÜ'de \%20,2 iken, bu oran UBC ve SFU'de çok daha düşük seviyelerde kalmıştır $(\% 6,25)$.

\section{Var Olan Belge Sistemine Yönelik Yaşanan Problemlerin Kaynağı}

Her iki ülke idari sistemi içerisinde yaşanan sorunların belirlenmesinin ardından, idari sistemin bir paçası olarak belge işlemlerine yönelik yaşanan problemlerin kaynağını tespit etme gereği hissedilmiştir. Bu kapsamda her iki ülke üniversite sistemi içerisinde aşağıdaki 
başlıklarda yaşanan sorunların boyutunun tespiti ve karşılaştırılması amaçlanmıştır. Bu kapsamda, deneklerin birden fazla seçenek işaretleyebildikleri soruların betimsel istatistikler ve frekans değerleri üzerinden karşılaştırmaya gidilmiştir.

Tablo 13. Belge Sistemine Yönelik Yaşanan Problemlerin Kaynağı

\begin{tabular}{llllll}
\hline & A & B & C & D \\
\hline UBC ve SFU & $\%$ & 25 & 33 & 12,5 & 29,50 \\
\hline HÜ & $\%$ & 27,6 & 12,5 & 39,3 & 20,6 \\
\hline
\end{tabular}

\section{A. Belge saklama planının eksikliği}

UBC ve SFU'de deneklerin \%25'i, HÜ'de ise deneklerin \%27,6'sı belge saklama planının eksikliğini, var olan belge sistemleri içerisinde yaşanan problemlerin kaynağı olarak göstermişlerdir.

\section{B. Dosya tasnif planındaki sorunlar}

UBC ve SFU'de denekler HÜ'ye göre daha yüksek oranda (UBC ve SFU \%33, HÜ \%12,5), dosya tasnif planından kaynaklanan sorunları, mevcut belge işlemlerinde yaşanan sıkıntıların kaynağı olarak işaretlemişlerdir.

\section{Belge işlemleri üzerine eğitim alt yapısının eksikliği}

HÜ'de deneklerin önemli bir bölümü, yürüttükleri belge işlemlerine yönelik herhangi bir eğitim çalışmasına katımadıklarını belirtmişlerdir (HÜ \%39,3). Öte yandan UBC ve SFU'de belge işlemlerine yönelik herhangi bir eğitim çalışmasına katılmayanların oranı HÜ'ne göre çok daha düşük düzeylerdedir (UBS ve SFU \%12,5).

\section{Belge işlemlerinin tanımlandığı idari ve yasal düzenlemelerdeki yetersizlikler}

Belge işlemlerine yönelik yaşanan problemler arasında yasal ve idari düzenlemelerdeki yetersizlikleri, UBC ve SFU'deki deneklerin $\% 29,5^{\prime}$ i işaretlemiştir. $\mathrm{Bu}$ oran HÜ'deki denekler arasında \%20,6 olarak gerçekleşmiştir. 


\section{Belge Erişime Dönük Yaşanan Problemlerin Kaynağı}

Belge yönetimi programlarının en önemli amaçlarından birisini, daha önce üretilen ya da sağlanan belgelerin elden geldiğinde hızlı ve etkin biçimde erişiminin sağlanması oluşturmaktadır. Bu kapsamda her iki ülke deneklerinin belge erişime dönük sorunları ne oranda yaşadıkları sorgulanmış, elde edilen sonuçların betimsel istatistikleri alınarak Tablo 14 'e yansıtılmıştır.

Tablo 14. Belge Erişime Dönük Yaşanan Problemlerin Kaynağı

\begin{tabular}{lllllll}
\hline & & A & B & C & D & E \\
\hline UBC ve SFU & $\%$ & 6,2 & 18,7 & 31,4 & 37,5 & 6,2 \\
\hline \multicolumn{10}{l}{ HÜ } & $\%$ & 27,4 & 20,5 & 27,4 & 19,6 & 5,1 \\
\hline
\end{tabular}

\section{A. Güncel olmayan belgeler zamanında ayıklanmaması}

Tablo 14'de yer alan verilerden UBC ve SFU'deki deneklerin, güncelliğini yitirmiş belgelerin zamanında ayıklanmaması konusunda, HÜ'deki denekleregöre çok daha az sorun yaşadığı sonucunu ortaya çıkmıştır (UBC ve SFU \%6,25, HÜ \%27,4). Bu durum, HÜ'de belge saklama planlarına duyulan gereksinimin boyutlarını ortaya koymaktadır.

\section{B. Aranan belgelerin kaybolması, imha edilmesi ya da yanlış yerleştirilmesi}

Belge erişim problemi olarak kayıp, imha ya da yanlış yerleştirme konularında HÜ'deki deneklerin biraz daha sorunlu olduğu görülmektedir. UBC ve SFU'de ilgili seçeneğin işaretlenme oranı \%18,75 iken HÜ'de bu oran \%20,5'e çıkmaktadır.

C. Belge erişim araçlarının yetersizliği (envanterler, indeksler, listeler vb. gibi)

Belge erişim araçlarının yetersizliği konusunda HÜ'deki denekler UBC ve SFU'de görevli meslektaşlarına göre biraz daha az sıkıntılı görülmektedirler. İlgili seçeneğin işaretlenme oranı HÜ'de \%27,4 iken UBC ve SFU'de bu oran \%31,4 olarak gerçekleşmiştir. . 


\section{Etkin olmayan dosyalama sistemi}

Daha önce dosya tasnif planına yönelik olarak, UBC ve SFU'deki deneklerin HÜ'deki deneklere göre daha sorunlu olduğunu ortaya çıkmıştı. Dosyalama sisteminin yetersizliği konusunda da UBC ve SFU'deki deneklerin HÜ'deki deneklere göre daha yoğun sorunlar yaşadığı görülmektedirler (UBC ve SFU \%37,5, HÜ \%19,6).

\section{E. Belgelere erişim konusunda engellemelerin olması}

Her iki ülke denekleri de belge erişimine yönelik engellemelerin, erişim problemine yol açtığını \%10'un altında düşük bir oranda işaretlemişlerdir (UBC ve SFU \%6,2, HÜ \%5,1).

\section{Belge Erişimine Dönük Sorunların Yaşanma Sıklığı}

Belge erişimine dönük problemlerin yaşanma sıklığınına ilişkin veriler Tablo 15'de izlenebilmektedir. Tablo 15 'de elde edilen veriler doğrultusunda HÜ'de deneklerin haftadan birkaç kez belge erişim sorunu yaşama olasılığı \%29,1 ile ilk sırada iken UBC ve SFU'de belge erişime dönük ayda birkaç kez sorun yaşama olasılığı \%37,5 ile ilk sıradır.

Tablo 15. Belge Erişimine Dönük Sorunların Yaşanma Sıklığı

\begin{tabular}{lcl}
\hline & UBC/SFU & HÜ \\
\hline Haftada en az birkaç kez & 18,5 & 29,1 \\
\hline Ayda en az birkaç kez & 37,5 & 24,4 \\
\hline Yılda birkaç kez & 6,25 & 20,3 \\
\hline Sorun Yaşamıyor & 37,75 & 26,2 \\
\hline
\end{tabular}

Elde edilen sonuçlar her iki ülkede de deneklerin yarıdan fazlasının ayda en az birkaç kez belge erişim sorunu yaşadığını göstermektedir.

\section{Belge Yönetimi Programları Uygulanmasının Sağlayacağı Olanaklar}

Belge yönetimi programları ve bunun bir parçası olarak belge saklama planları, araştırmamızın Türkiye örneklemini oluşturan Hacettepe Üniversitesinde hâlihazırda uygulanmamaktadır. Bu çerçevede, Kanada'da incelemelerin gerçekleştirildiği UBC ve SFU içerisinde belge işlemlerini 
yürüten ya da bu işlemlerden sorumlu personel ile HÜ'nde böyle bir programın uygulanmasıyla sağlanabilecek olası yararlar sorgulanmış, ardından HÜ örneğinde daha önce gerçekleştirilen aynı içerikli analiz ile karşılaştırılmış ve aşağıdaki sonuçlar elde edilmiştir.

Tablo16. Belge Yönetimi Programları Uygulanmasının Sağlayacağı Olanaklar

\begin{tabular}{lcc}
\hline & UBC ve SFU & HÜ \\
\hline Standartlaşmaya katkı sağlar & 37,5 & 62,4 \\
\hline Belge işlemleri etkinleşir & 82,25 & 59,1 \\
\hline Kurumsal arşiv çalışmaları rahatlar & 12,5 & 38,2 \\
\hline $\begin{array}{l}\text { Gerekli belgelerin imhasının ve gereksiz belgelerin } \\
\text { depolanmasının önüne geçilebilir }\end{array}$ & 50,0 & 59,1 \\
\hline Hiçbir katkı sağlamaz &, 0 & 11,3 \\
\hline
\end{tabular}

UBC ve SFU'de görevli denekler, kendi deneyimlerine de dayanarak, Türkiye üniversitelerinde belge yönetimi programlarının ve buna bağlı belge saklama planlarının geliştirilmesiyle, özellikle belge işlemlerinin etkinleşeceğini düşünmektedirler (UBC ve SFU \%82,25). Bu seçeneğin HÜ'de işaretlenme oranı \%59,1'dir. HÜ'de denekler belge yönetimi programlarına geçişle standartlaşmanın artacağını dile getirirken (HÜ \%62,4) bu oran UBC ve SFU'de \%37,5'de kalmaktadır. UBC ve SFU'de denekler, gerekli belgelerin zamanından önce imhasının önüne geçilmesi ve gereksiz belgelerin uzun yıllar depolarda saklanmasının engellenmesini, sağlanacak katkılar arasında \%50 oranında bir işaretlemeyle gösterilmişlerdir. UBC ve SFU'de deneklerin belge yönetimi programların yaratabileceği olumsuz koşullar üzerine görüş bildirmezken bu oran HÜ'de \%11,3'de kalmıştır.

\section{Sonuç}

Türkiye'de üniversitelere yönelik belge yönetimi programlarının geliştirilmesine, uluslararası örneklerle yapılacak karşılaştırmalı çalışmaların katkı yapacağı düşünülmektedir. Bu çerçevede Kanada örneklerini oluşturan UBC ve SFU ile Türkiye örneğini oluşturan HÜ belge sistemlerinin mevcut durumu, sorunları ve beklentilerin karşılaştıııması sonucu aşağıdaki sonuçlara ulaşılmıştır.

Yukarıdaki tabloda denekler birden çok seçenek işaretlediklerinden oranlar \%100'ün üzerinde çıkmaktadır. 
Belgeler kurumlarda her iş sürecinin gerektirdiği yasal ve idari koşulların dokümantasyonunu oluşturmaktadırlar. Belgeler ve bir bütün olarak belge sistemlerinde gerçekleştirilecek değişikliklerin, kurumsal iş süreci ve bunu ortaya koyan bürokrasi üzerine etkisi unutulmamalıdır.

Kuruluşundan itibaren "daha iyisini, en iyisini” hedefleyen HÜ'de, belge sistemleri üzerine gerçekleştirilen ve eleştirileri de çalışmanın, bu hedefe katkı sağlaması amaçlanmaktadır. Kanada'da inceleme ve araştırmaların yürütüldüğü UBC bilimsel ve toplumsal yaşama sağladığı katma değerle, SFU ise belirli alanlarda yoğunlaşan nitelikli insan gücü yetiştirme politikalarıyla ön plana çıkmaktadırlar. Kanada örneklerini oluşturan her iki üniversite idari sistemi içerisinde belge yönetimi programları uygulanmaktadırlar. Her iki üniversitede, kurumsal belge ve arşiv çalışmalarını koordine eden ve yöneten, bünyesinde ilgili alanda profesyonellerin görev yaptığı merkezi belge yönetimi ve arşiv yönetimi birimlerine sahiptir. Kanada örneklerinde belge yönetimi programları, merkezi birimlerin denetiminde geliştirilen el kitapları ve düzenlemeler çerçevesinde, ilgili birimlerde görevli personellere dayanarak uygulanmaktadır. Öte yandan Türkiye örneğini oluşturan HÜ içerinde, belge işlemlerinin yürütülmesi ve koordinasyonuna yönelik bir belge yönetimi birimi olmamakla birlikte, Genel Sekterliğe bağlı idari çalışanlar ve Dış Illişkiler Müdürlüğü ilgili çalışmalarda sorumluluk taşımaktadır. HÜ ayrıca daire başkanlıkları ve ilgili birimler dışında merkezi bir üniversite arşivine de sahip değildir.

Yapılan analizler sonucu HÜ içerisinde belge işlemlerini yürüten personelin çok büyük bir bölümünün, ilgili alanda hiçbir eğitim çalışmasına katılmadığı ortaya çıkmıştır. Oysa Kanada örneklerinde çok daha farklı bir tablo söz konusudur. Belge işlemlerine yönelik onlarca ulusal ve uluslararası düzenlemeye, uygulamalarda uyum ve eşgüdüm için gerçekleştirmeye yönelik girişim ve geliştirilen rehberlere karşın HÜ'de ortaya çıkan bu tablonun bir an önce değişmesi gerekmektedir. Bu durumun HÜ'de belge yönetimi alanında merkezi bir otorite eksikliğinin sonucu olarak ortaya çıktığı düşünülmektedir.

Her iki ülke örneklerinde gerçekleştirilen analizler sonucu, kullanılan ağırlıklı belge türlerinin yazışmalar, formlar, talimatlar ve raporlardan oluştuğu ortaya çıkmıştır. Öte yandan Kanada örneklerinde 
elektronik ortamda belge üretimi ve kullanımının neredeyse basılı belgelere eşit düzeye erişmesi dikkat çekmektedir. Belge işlemlerinde elektronik ortamın kullanımının hız ve etkinliğin artırıması, depolama ve gereksiz personel istihdamının önüne geçilmesi vb. konularda son derece önemli olduğu düşünülmektedir. Gerekli güvenlik koşullarının yerine getirilmesi, belgelerin yaşam döngüsünün bütünü ile arşiv çalışmalarını da içine alan yazııım olanaklarının sağlanması ve alt yapı koşullarının uygun hale getirilmesiyle, HÜ'de elektronik belge yönetimi uygulamalarına geçişi engelleyecek herhangi bir idari ve yasal koşul söz konusu değildir.

Üretimlerini takip eden belirli bir sürede güncel olan belgelere erişim, idari işleyişinin günlük bir parçasıdır. Daha önce alınmış kararlara, gerçekleştirilmiş uygulamalara ve geçmişe dönük bilgi gereksinimine güvenilir ve ilk elden kaynak oluşturan belgelere erişimde yaşanacak aksamalar, yönetsel uygulamaların da aksamasına neden olabilmektedir. Kanada örneklerinde belge erişimde elektronik ortamın kullanımı \%60'ların üzerindeyken Türkiye örneğini oluşturan HÜ'de bu oranı \%19,9'da kalmıştır. Belgelerin tam metinler olmasa dahi envanter bilgilerinin elektronik ortama aktarımasının, belge erişim probleminin çözümünde aşama sağlayacağı düşünülmektedir.

İnceleme ve araştırmaların gerçekleştirildiği her iki ülkede de belge düzenleme, saklama ve ayıklama uygulamalarına ilişkin yönetmelikler olmasına karşın, çalışma içerisinde yer aldığı gibi HÜ'de bu konuda ciddi problemler söz konusudur. Bu durumun en önemli nedeninin, HÜ'de belgelerin üretimden itibaren ayıklanması ya da arşive kaldırımasına kadar olan süreci tanımlayan, belge saklama ve ayıklama planlarının olmayışı olduğu düşünülmektedir. Nitekim Kanada örneklerinde daha güncel dosyalarda ayıklamaya tabii tutulan belgelerin, Türkiye örneklerinde büyük bir çoğunluğunun arşivlere geldikten sonra ayıklanmaya çalışılması bu yargıyı desteklemektedir. Hâlihazırda HÜ örneğinde deneklerin yarısından fazlasının, üretilen ve kullanılan belgelere yönelik hiçbir ayıklama ve imha çalışmasını yürütmediklerini dile getirmeleri, geçmiş belgelerin gittikçe içinden çıkılması zorlaşan yığınlara dönüşmesine yol açmaktadır. 
Her iki ülke örneklerinde denekler belge işlemlerine yönelik bir iş gününde ortalama 3 saat civarında zaman harcadıklarını dile getirmişlerdir. Bu süreçte belge erişim problemlerini her iki ülke için de ayda en az birkaç kez yaşama oranı \%50'civarındadır. Bunun Kanada örneklerindeki temel nedenini dosya tasnif planı uygulamalarındaki yetersizliklerde aramak mümkündür (Kanada örneklerinde denekler Türkiye örneğine göre dosyalama alanında daha yoğun sorun yaşadıklarını dile getirmişlerdir). Türkiye örneğinde sorunların kaynağında, belge yönetimi programları ve belge saklama planlarının geliştirilmemiş olması ve elektronik ortamdan yeterince yararlanılmıyor oluşu önemli etkenler arasındadır. Öte yandan Devlet Arşivleri Genel Müdürlüğü (DAGM) ile T.C. Başbakanlığına bağı çeşitli birimlerde başlatılan ve "eTürkiye" projesi kapsamında geliştirilen "Standard Dosya Planı" uygulamasına, HÜ henüz geçiş sağlayamamıştır. Pek çok yükseköğretim kurumu gibi, inceleme ve araştırmaların yürütüldüğü HÜ'de, elektronik ortamda dosyalamaya elverişli olarak geliştirilen Standart Dosya Planına" uygulamasına geçişin, ulusal düzeyde eşgüdümlü uygulamalara sağlayacağı katkı yanında, kurumsal düzeyde 1977 tarihinden kalma "Desimal Dosya Uygulamasının" yenilenmesi açısından da gerekli olduğu düşünülmektedir (Standart Dosya Planı, 2005; Hacettepe Üniversitesi Desimal Dosya, 1977).

Kanada örnekleri ile Türkiye örneğini oluşturan HÜ'de idari yapı ve buna bağlı belge işlemleri karşıllaştııılığında; iletişim ve eşgüdüm, çalışanlar arasında uyum ve çalışma koşullarını belirleyen yasal düzenlemeler konusunda her iki ülke içerisinde de orta düzey sorunlar yaşandığı görülmektedir. Her ne kadar Türkiye örneğinde sorunların yoğunluğu daha fazla görülse de, koşuların her iki ülke için de olumsuz olduğunu söylemek mümkündür. Öte yandan etkin olmayan bürokrasi konusunda Türkiye'deki deneklerin $\% 23,9$ 'u şikayetçi iken Kanada örneklerinde bu oran \%37,5'e çıkmaktadır. Yine Türkiye'de denekler, resmi iletişimi sağlayan belgelere yönelik etkin bir sistemin eksikliği ve gerekli belgelere zamanında erişim problemlerini \%18 oranında işaretlerken, aynı konuda Kanada'da deneklerin işaretleme oranı \%25'e çıkmaktadır. Tüm bu sorunların kaynağı olarak Türkiye'de deneklerin \%39,3'ü belge işlemlerine yönelik eğitim altyapısındaki eksikliği, \%27,6'sı ise 
belge yönetimi programları ve belge saklama planlarının bulunmayışını göstermişlerdir. Öte yandan Kanada'dai denekler ise yaşadıkları sorunların başıca kaynağını dosyalama sisteminde görmektedirler.

Elde edilen veriler çerçevesinde Türkiye örneğini oluşturan HÜ'de idari yapının ve buna bağlı belge işlemlerinin daha sistematik ve önceden belirlenmiş programlar çerçevesinde tanımlanmasıyla, deneklerin de dile getirdiği gibi, ilgili alanlarda sorunların azaltılabileceği göz önünde bulundurulmalıdır. Çalışmada ortaya konuluğu gibi Türkiye örneğinde belge erişimine dönük yaşanan problemlerin önemli bir nedeni olarak, belgelerin zamanında ayıklanmaması ve dolayısıyla gereksiz belgeler arasından gerekli belgelere erişimin güçleşmesi ve içerisine elektronik erişim unsurlarının da yer aldığı belge erişim araçlarındaki yetersizlikler gösterilmektedir. Yine aranan belgelere kayıp, imha ya da yanlış yerleştirme yüzünden erişilememesi $(\% 20,5)$ ve etkin olmayan dosyalama sistemi (Kanada örneklerinde $\% 37,5$, Türkiye örneğinde $\% 19,6$ oranında işaretlenmiştir) seçenekleri azımsanmayacak oranlarda işaretlenmişlerdir. Tüm bu sorunlar, belgelerin yaşam evrelerinin tümünü içine alacak belge yönetimi programları ve belge saklama planlarının geliştirilmesiyle aşılabilecektir.

Kanada'da denekler Türkiye'de üniversitelerde belge yönetimi programlarının uygulanması ve belge saklama planlarının geliştirilmesiyle, \%82,2 gibi yüksek bir oranda belge işlemlerinin etkinleşeceğini, $\% 50$ oranında gereksiz depolamanın önüne geçilebileceğini, \%37,5 oranında da standartlaşmaya katkı sağlanabileceğini belirmişlerdir. Türkiye'deki denekler kendi kurumlarında belge yönetimi programlarına geçişle en çok standartlaşmanın sağlanabilmesini $(\% 62,4)$, belge işlemlerinin etkinleşmesini $(\% 59,1)$ ve gereksiz belgelerin depolanmasının önüne geçilmesini $(\% 59,1)$ beklemektedirler. Hiçbir katkı sağlamaz seçeneği Kanada'da işaretlenmezken Türkiye'de bu seçeneğin işaretlenme oranı \%11,3'de kalmaktadır. Her iki ülkede belge işlemlerini yürüten ya da bu işlemlerde sorumluluğu olan personelin de dile getirdiği gibi, Türkiye örneğini oluşturan HÜ'de ve belge yönetimi programları uygulanmayan Türk Yükseköğretim Sistemi içerisindeki diğer üniversitelerin, mevcut idari sistemlerinde ve buna bağlı belge işlemlerinde etkinlik ve verimliliğe ulaşmada, belge yönetimi 
programları önemli bir katkı sağlayabilecektir. Kanada örneklerinde ilgili alanlarda sorunların daha az yaşanması, belge yönetimi programları ve belge saklama planlarının uygulanıyor oluşu ile doğru orantılıdır. Bu çerçevede çalışma kapsamında ortaya konan hususların, belge yönetimi programları uygulanmayan HÜ'de ve genel olarak Türkiye'de aynı yapı ve idari işleyişe sahip diğer üniversitelerde belge yönetimi programlarının geliştirilmesine katkı sağlaması umulmaktadır.

\section{Kaynakça}

Baş, T. (2001). Anket: Anket nasıl hazılanır, anket nasıl uygulanır, anket nasıl değerlendirilir. Ankara: Seçkin.

Brumm, E. (1995). Managing records for ISO 9000 compliance. Wisconsin: ASQC Quality Press.

Çiçek, N. (2000). ISO 9000 Kalite güvence sistemi standardında evrak üretimi ve yönetimi. Arşiv Araştırmaları Dergisi, 2, 7-34.

Glossary of Records Management Terms.(1989). Prairie Village: KS: Association of Records Managers and Administrators.

Hacettepe Üniversitesi Desimal Dosya Sistemi Yönergesi. Hacettepe Üniversitesi Rektörlük Makamı, 1.11.1977, Sayı: 260/1739.

Hacettepe Üniversitesi Strateji Geliştirme Daire Başkanlığı. (2006). Bütçe uygulamaları sonuçları konusunda kamuoyunu bilgilendirme duyurusu. 14 Ağustos 2006 tarihinde Hacettepe Üniversitesi Web sitesinden erişildi: http://72.14.253.104/search?q= cache:iLk11gMN_z0J:www.hacettepe.edu.tr/duyuru/rekduy/butceuy gulamason.pdf+Hacettepe+\%C3\%9Cniversitesi+B $\%$ C3\%BCt\%C3 $\% A 7 e s i \% 22 \& h l=t r \& g l=t r \& c t=c l n k \& c d=1$ a

Hare, C. E. (1997). Developing a record management programme. London: Aslib.

İcimsoy, A. O. (1997). Arşivlerde mikroform kullanımı: Yeni teknolojiler ve sorunlar. Bilgi Çağı, Bilgi Merkezleri ve Bilgi Teknolojileri Sempozyumu 7-9 Mayıs 1997 - Bildiriler içinde (ss. 7-14). Ankara: Ankara Üniversitesi, 1999. 
Kandur, H. (1998). Arşivlerde kullanıcı hizmetleri ve bilgisayar kullanımı.

I. Milli Arşiv Şurası (Tebliğler-Tartışmalar) <20-21 Nisan 1998 Ankara> içinde (ss. 579-588). Ankara: Başbakanlık Devlet Arşivleri Genel Müdürlüğü, 1998.

Kandur, H. (2006). Elektronik belge yönetimi sistem kriterleri referans modeli. İstanbul: Devlet Arşivleri Genel Müdürlüğü. 1 Haziran 2007 tarihinde http://www.devletarsivleri.gov.tr/EBYS_v_2_0.pdf adresinden erişildi.

Külcü, Ö. (2005). Kamu üniversitelerinde kalite yönetimi ve kalite sistem dokümantasyonu çerçevesinde belge yönetimi. Yayımlanmamış doktora tezi, Hacettepe Üniversitesi, Ankara.

Külcü, Ö. (2006). Küreselleşme sürecince Avrupa Birliği'nde belge yönetimi uygulamaları ve Türkiye. Bilgi Dünyası, 7 (2), 202-229.

Montana, J. (1997). Statutes of limitation and records retention. Records Management Quarterly, 31 (1), 46-63.

Odabaş, H. (2007). Elektronik belge yönetimi ve kamu kurum ve kuruluşları. Yayımlanmamış doktora tezi, Ankara: Ankara Üniversitesi.

Özdemirci, F. (1996). Kurum ve kuruluşlarda belge üretiminin denetimi ve belge yönetmi. İstanbul: Türk Kütüphaneciler Derneği İstanbul Şubesi Yayınları.

Özdemirci, F. (2004). Bir disiplin olarak belge yönetim. S. Arslantekin ve F. Özdemirci (Yay. Haz.), Kütüphaneciliğin Destanı Uluslar arası Sempozyumu 21-24 Ekim 2004, Ankara: (Bildiriler) içinde (ss. 191210). Ankara: A.Ü. DTCF Bilgi ve Belge Yönetimi Bölümü.

Penn, I. A., Mordel, A. ve Penix, G. (1994). Record management handbook. Aldershot, Hants : Ashgate.

Shiff, R. A. (1995). The archivist's role in records management. American Archivists, 19 (3), 111.

Skupsky, D. S. (1994). Records retention procedures: your guide to determine how long to keep your records and how to safely destroy them. Englewood: Information Requirement Clearinghouse. 
Simon Fraser University. (2006). About Simon Fraser University. 7 Ağustos.2006 tarihinde http://www.sfu.ca/aboutindex.html. adresinden erişildi.

Smith, R. J. ve Kallaus, N. F. (1997). Records management. Cincinnati: South Western Education Publishing.

Standart Dosya Planı ile Illgili Başbakanlık Genelgesi. T.C. Başbakanlık Personel ve Prensipler Genel Müdürlüğü, 24 Mart 2005, Sayı: 3203802: $1-55$.

Stephens, D. O. (1995). International records retention. Records Management Quarterly, 29 (4), 69-75.

Toope, S. J. (2006). President's welcome. 7 Ağustos 2006 tarihinde University of British Columbia Web sitesinden erişildi: http://www.ubc.ca/about/welcome.html

TS ISO 15489-1. (2007). Bilgi ve dokümantasyon - Belge yönetimi Bölüm 1: Genel. Türk Standartlar Örgütü: Ankara

TSE ISO/TR 15489-2. (2007). Bilgi ve dokümantasyon - Belge yönetimi Bölüm 2: Kılavuzlar. Türk Standartlar Örgütü: Ankara.

Türk Standartları Enstitüsü. (2007). Bilgi ve dokümantasyon - Elektronik belge yönetimi. (TSE 13298). 1 Kasım 2007 tarihinde http://www.tse.org.tr/Turkish/Abone/Standard_Ara.asp?Durum=IcsT ablosu\&Sira=1\&EskiKod=01.110 adresinden erişildi. 